\title{
Relaxing Effect of TSU-68, an Antiangiogenic Agent, on Mouse Airway Smooth Muscle
}

\author{
Honghao Tan ${ }^{a}$ Jun Lei ${ }^{a}$ Lu Xue ${ }^{a}$ Congli Caib Qing-hua Liu ${ }^{a}$ Jinhua Shen ${ }^{a}$ \\ aInstitute For Medical Biology and Hubei Provincial Key Laboratory for Protection and Application \\ of Special Plants in Wuling Area of China, College of Life Sciences, South-Central University for \\ Nationalities, ${ }^{b}$ Wuhan Youzhiyou Biopharmaceutical Co., Ltd., Biolake, Wuhan, China
}

\section{Key Words}

TSU-68 • Small-molecule chemical compound $\bullet$ Pulmonary disease $\bullet$ VDCCs $\bullet$ NSCCs

\begin{abstract}
Background/Aims: Recently, some small-molecule compounds that were designed for cancer therapy have acquired new roles in the treatment of pulmonary diseases. However, drug screening aimed at abnormal muscle contraction is still limited. TSU-68 is a potent, orally administered, small-molecule agent that can reduce the vascular endothelial growth factor (VEGF)-induced $\mathrm{Ca}^{2+}$ increase in endothelial cells. We questioned whether TSU-68 could also affect calcium influx and relax airway smooth muscle (ASM) cells. The current study aimed to investigate these effects and to explore the underlying mechanisms. Methods: The effects of TSU-68 on ASM cells were studied in mice using a series of biophysiological techniques, including force measurement and patch-clamp experiments. Results: TSU-68 inhibited high K+ or acetylcholine chloride ( $\mathrm{ACh}$ )-induced pre-contracted mouse tracheal rings in a concentrationdependent manner. Further research demonstrated that the TSU-68-induced ASM relaxation was mediated by calcium, which was decreased by blocking voltage-dependent $\mathrm{Ca}^{2+}$ channels (VDCCs) and non-selective cation channels (NSCCs). Conclusion: Our data indicated that TSU-68 relaxes tense ASM by reducing the intracellular $\mathrm{Ca}^{2+}$ concentration through blocking VDCCs and NSCCs, which suggested that this small molecule might be useful in the treatment of abnormal smooth muscle.

\section{Introduction}

Pulmonary diseases are a series of debilitating, life-threatening respiratory illnesses that have become severe worldwide public health problems and a financial burden [14]. Airway inflammation, excessive cell matrix proliferation, and especially the abnormal contraction of airway smooth muscle cells are the main symptoms of pulmonary diseases [5H. Tan, J. Lei and L. Xue contributed equally to this work. 


\section{Cellular Physiology Cell Physiol Biochem 2017;41:2350-2362 \begin{tabular}{l|l} 
DOI: 10.1159/000475653 & Ond 2017 The Author(s). Published by S. Karger AG, Basel \\
www.karger.com/cpb
\end{tabular} \\ Tan et al.: TSU-68 Relaxes Smooth Muscle in the Mouse Airway}

7]. The development of more effective medications for pulmonary diseases and improving quality of life without side effects are urgently needed.

Recent studies have revealed that quite a few angiogenic and inflammatory signal pathways are shared in both pulmonary diseases and cancer. Fibroblast growth factors (FGF), platelet-derived growth factors (PDGF), vascular endothelial growth factors (VEGF), and inflammatory factors (IF) and their receptors (FGFR, PDGFR, VEGFR, and IFR, respectively) as well as calcium and calcium permeable channels, which are pivotal targets of anticancer treatments [8-17], are also critical factors for inflammation, extracellular matrix proliferation, and abnormal smooth muscle contraction in pulmonary diseases [18-24]. Considering the roles of these processes in pulmonary diseases, we could readily screen for pulmonary disease medications using established molecular cancer drugs. Recently, several bioavailable small-molecule agents have been evaluated for their efficacy in a series of respiratory diseases and their complications, including chronic obstructive pulmonary disease (COPD), idiopathic pulmonary fibrosis (IPF), and asthma, etc [25]. For example, recent pharmaceutical and clinical research has demonstrated that BIBF1120, a potent triple blocker of PDGFR, VEGFR, and VEGFR, has significant antitumor efficacy in the treatment of non-small cell lung cancer (NSCLC) $[26,27]$ and reduces the loss of lung function in IPF [12, 28-30]. Gefinitib, which is also an effective small-molecule agent in NSCLC therapy, plays a new role in asthma treatment via inhibiting airway remodeling and inflammation [31]. As a CXC chemokine receptor (CXCR) antagonist, SCH-527123 can inhibit excessive CXCR activation of neutrophils and prevent pulmonary inflammation [32]. SCH527123 has undergone clinical trials in a number of airway inflammatory diseases, such as COPD, allergen-induced asthma, and neutrophilia-induced asthma [32-34]. Metoprolol, a first-line drug for angina and hypertension, might be applied in cardiac complications during treatment of pulmonary diseases [35]. The breakthrough of using small-molecule compounds as treatments for respiratory diseases has demonstrated that further investigations of other therapies, including angiogenetic inhibitors, might lead to new treatments for these illnesses.

Nonetheless, drug screening aimed at mitigating excessive abnormal contraction in airway smooth muscle (ASM), which is a key symptom of pulmonary disease, has been limited. The small-molecule compound TSU-68, a known tyrosine kinase inhibitor that can reduce VEGF-evoked calcium and inhibit the kinase activity of VEGFR, has been developed as an angiogenesis inhibitor in oncotherapy, especially for solid tumor treatment [36-38]. In the current study, we investigated the roles of TSU-68 in pulmonary disease therapy with a focus on ASM relaxation. The results showed that contracted mouse ASM could be relaxed by TSU-68 in a concentration-dependent manner. Further research indicated that TSU-68 exerted its relaxant effects by decreasing intracellular calcium via voltage-dependent $\mathrm{Ca}^{2+}$ channels (VDCC) and non-selective cation channels (NSCC), probably through transient potential canonical (TRPC) channels.

\section{Materials and Methods}

Reagents and chemicals

TSU-68 was purchased from Selleck Chemical Reagent Co. (Shanghai, China). Acetylcholine chloride (ACh), gadolinium, pyrazole 3 (Pyr3), niflumic acid (NA), nifedipine, and tetraethylammonium chloride (TEA) were purchased from Sigma Chemical Co. (St. Louis, MO, USA). All other chemicals were purchased from Sinopharm Chemical Reagent Co. (Shanghai, China).

Animals

Sexually mature male BALB/c mice were purchased from the Hubei Provincial Center for Disease Control and Prevention (Wuhan, China). The mice were housed in a specific pathogen-free (SPF)-grade laboratory under a $12 \mathrm{~h}$ light-dark cycle. All animal experiments were approved by the Animal Care and Ethics Committee of the South-Central University for Nationalities (Wuhan, China) and were performed under the supervision of the Institutional Animal Care and Use Committee of the South-Central University for Nationalities (Wuhan, China). 


\section{Cellular Physiology Cell Physiol Biochem 2017;41:2350-2362 \begin{tabular}{l|l} 
and Biochemistry Published ondine: April27, 2017 & $\begin{array}{l}\text { C } 2017 \text { The Author(s). Published by S. Karger AG, Basel } \\
\text { www.karger.com/cpb }\end{array}$
\end{tabular} \\ Tan et al.: TSU-68 Relaxes Smooth Muscle in the Mouse Airway}

\section{ASM contraction measurement}

Mouse ASM contraction was measured in tracheal rings. The mice were sacrificed by cervical dislocation and the tracheas were isolated and quickly transferred to ice-cold PSS (in mM: $\mathrm{NaCl} 135, \mathrm{KCl}$ $5, \mathrm{MgCl}_{2} 1, \mathrm{CaCl}_{2} 2$, HEPES 10, glucose 10, $\mathrm{pH} 7.4$ ). The connective tissues were removed, and the tracheal rings ( $5 \sim 7 \mathrm{~mm}$ ) were cut from the bottom of the tracheas. Each ring was mounted with a preload of $0.5 \mathrm{~g}$ in a $10 \mathrm{~mL}$ organ bath containing PSS bubbled with $95 \% \mathrm{O}_{2}-5 \% \mathrm{CO}_{2}$ at $37^{\circ} \mathrm{C}$. Tracheal rings were equilibrated for $60 \mathrm{~min}$, pre-contracted with either $80 \mathrm{mM}$ of high $\mathrm{K}^{+}$or $100 \mu \mathrm{M}$ of $\mathrm{ACh}$, washed, and rested 3 times. The experiments were performed following an additional $30 \mathrm{~min}$ of rest. Based on tension experiment design, particular channel inhibitors including nifedipine $(10 \mu \mathrm{M})$, Pyr3 $(30 \mu \mathrm{M})$, and gadolinium $(30 \mu \mathrm{M})$ were applied in ASM contraction measurements, respectively.

\section{Isolation of ASM cells}

Mouse ASM cells were isolated as described previously [39-41]. Briefly, tracheas were isolated as described above in ASM dissociation buffer (in mM: NaCl 136, KCl 5.36, $\mathrm{KH}_{2} \mathrm{PO}_{4} 0.44, \mathrm{NaHCO}_{3} 4.16$, $\mathrm{Na}_{2} \mathrm{HPO}_{4} \cdot 12 \mathrm{H}_{2} \mathrm{O} 0.34$, HEPES 20 , glucose $10, \mathrm{pH} 7.1$ ). The isolated tracheas were then digested in ASM dissociation solution containing $3 \mathrm{mg} / \mathrm{mL}$ papain, $0.15 \mathrm{mg} / \mathrm{mL}$ dithioerythritol, and $1 \mathrm{mg} / \mathrm{mL}$ bovine serum albumin (BSA) at $35^{\circ} \mathrm{C}$ for $22 \mathrm{~min}$. The tissues were transferred to ASM dissociation buffer containing $1 \mathrm{mg} /$ $\mathrm{mL}$ collagenase $\mathrm{H}$, and $1 \mathrm{mg} / \mathrm{mL} \mathrm{BSA}$ and were incubated at $35^{\circ} \mathrm{C}$ for $8 \mathrm{~min}$. The tissues were washed and gently triturated with $1 \mathrm{mg} / \mathrm{ml}$ BSA to yield single ASM cells for use in subsequent experiments.

\section{Measurement of VDCC currents}

The VDCC currents were measured using an EPC-10 patch-clamp amplifier (HEKA, Lambrecht, Germany). $\mathrm{Ba}^{2+}$ was used as a charge carrier. The pipette was filled with intracellular solution containing $130 \mathrm{mM} \mathrm{CsCl}, 10 \mathrm{mM}$ EGTA, $4 \mathrm{mM} \mathrm{MgCl}$, 4 mM Mg-ATP, $10 \mathrm{mM}$ HEPES, and $10 \mathrm{mM}$ TEA, and was adjusted with $\mathrm{CsOH}$ to $\mathrm{pH}$ 7.2. The bath solution contained (in $\mathrm{mM}$ ) $107 \mathrm{mM} \mathrm{NaCl}, 27.5 \mathrm{mM} \mathrm{BaCl}, 10 \mathrm{mM}$ HEPES, $11 \mathrm{mM}$ glucose, and $10 \mathrm{mM}$ TEA, and was adjusted with $\mathrm{NaOH}$ to $\mathrm{pH}$ 7.4. ASM cells were patched and held at $-70 \mathrm{mV}$. Currents were measured following depolarization for $500 \mathrm{~ms}$ from -70 to $+40 \mathrm{mV}$ in $10 \mathrm{mV}$ increments every $1 \mathrm{~s}$. Based on patch experiments design, nifedipine $(10 \mu \mathrm{M})$ was applied in VDCC current measurement.

\section{Measurement of NSCC currents}

For the measurement of NSCC currents, the pipette solution contained (in mM) CsCl 126, $\mathrm{MgCl}_{2} 1.2$, HEPES 10, EGTA 3, and $\mathrm{CaCl}_{2} 1$ and was adjusted with Tris to pH 7.2. The composition of the bath solution contained (in mM) NaCl 126, CaCl 1.5, HEPES 10, and glucose 11 at $\mathrm{pH} 7.2$. The free $\mathrm{Ca}^{2+}$ concentration was approximately $70 \mathrm{nM}$ as calculated using WEBMAXC STANDARD (http://www.stanford.edu/ cpatton/ webmaxc/webmaxcS.htm). The bath solution was $\mathrm{K}^{+}$-free PSS. To block VDCC, $\mathrm{Cl}^{-}$, and $\mathrm{K}^{+}$currents, $10 \mu \mathrm{M}$ nifedipine, $100 \mu \mathrm{M} \mathrm{NA}$, and $10 \mathrm{mM}$ TEA, respectively, were added to the bath solution. NSCC currents were recorded with a ramp using a perforated whole-cell configuration with a holding potential of -60 mV. The ramp was performed over $500 \mathrm{~ms}$ from -80 to $+60 \mathrm{mV}$. Based on patch experiments design, nifedipine (10 $\mu \mathrm{M})$ was applied in VDCC current measurement. Based on experiments design, nifedipine (10 $\mu \mathrm{M})$, NA (100 $\mu \mathrm{M})$, TEA (10 mM) were applied in NSCC current measurement, respectively.

\section{Statistical analysis}

The results are expressed as the means \pm SEM. For all analyses, the evaluations were performed with Student's $t$-test using Origin 9.0 software (OriginLab, Northampton, USA). $p<0.05$ was considered to be statistically significant.

\section{Results}

TSU-68 relaxed high $\mathrm{K}^{+}$-induced pre-contraction in a dose-dependent manner

A high $\mathrm{K}^{+}$concentration induces smooth muscle contraction through the membrane depolarization-VDCC opening-calcium influx pathway [42, 43]. For this reason, the relaxant characteristic of TSU-68 was tested under conditions of high $\mathrm{K}^{+}$. Before the experiment, 
Fig. 1. Relaxant effects of TSU-68 on high $\mathrm{K}^{+}$-induced pre-contraction. (A) High $\mathrm{K}^{+}$induced a steady-state contraction in a mouse tracheal ring, which was inhibited by TSU-68 in a dose-dependent manner. (B) Dose-relaxation curve of TSU-68 based on the results of 7 different experiments (shown in A). (C) High $\mathrm{K}^{+}$-induced pre-contraction was completely reversed by nifedipine ( $\mathrm{n}=6 / 6$ mice). (D) TSU-68 had no effect on resting tension $(n=4 / 4$ mice).
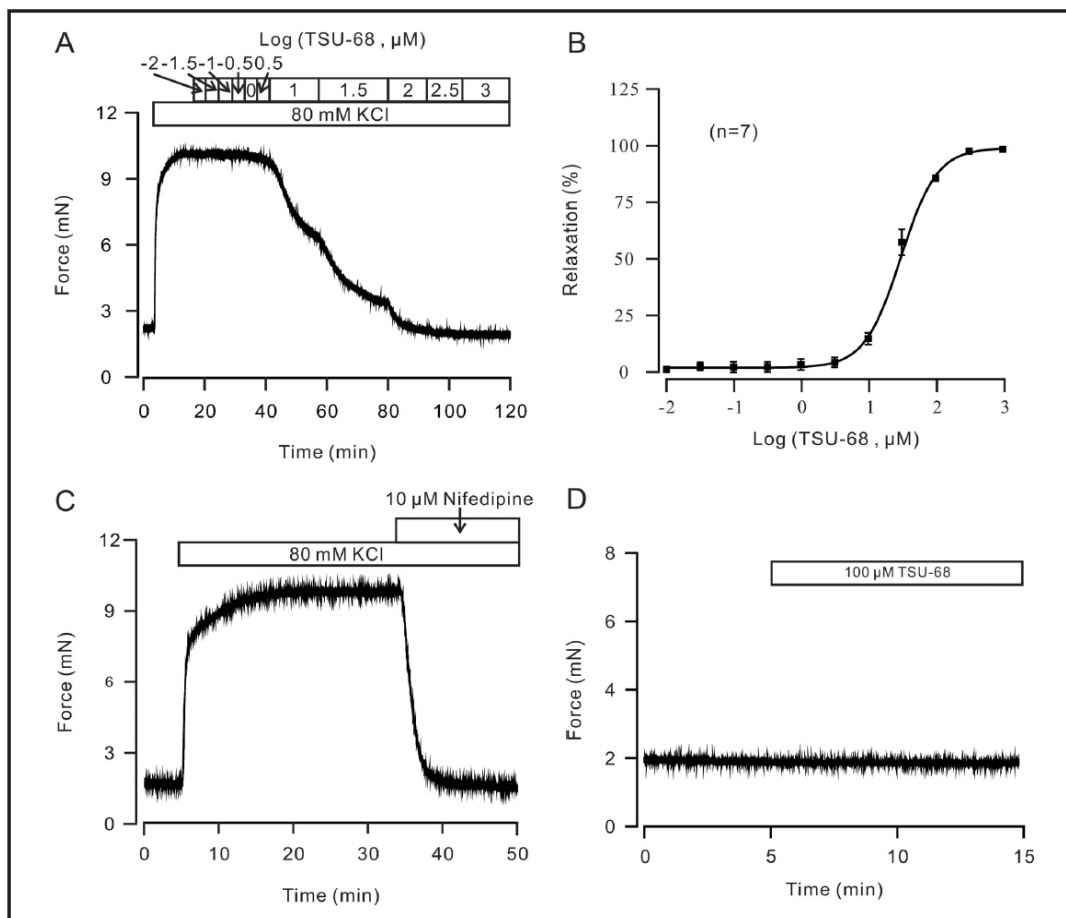

Fig. 2. TSU-68 blocked high $\mathrm{K}^{+}$-induced $\mathrm{Ca}^{2+}$ influx. (A) Under $\mathrm{Ca}^{2+}$ free conditions $(0 \mathrm{mM}$ $\mathrm{Ca}^{2+}$ and 0.5 mM EGTA), high $\mathrm{K}^{+}$did not evoke contraction in a tracheal ring. After restoration of $2 \mathrm{mM} \mathrm{Ca}{ }^{2+}$, a sustained contraction occurred, which was mostly inhi-

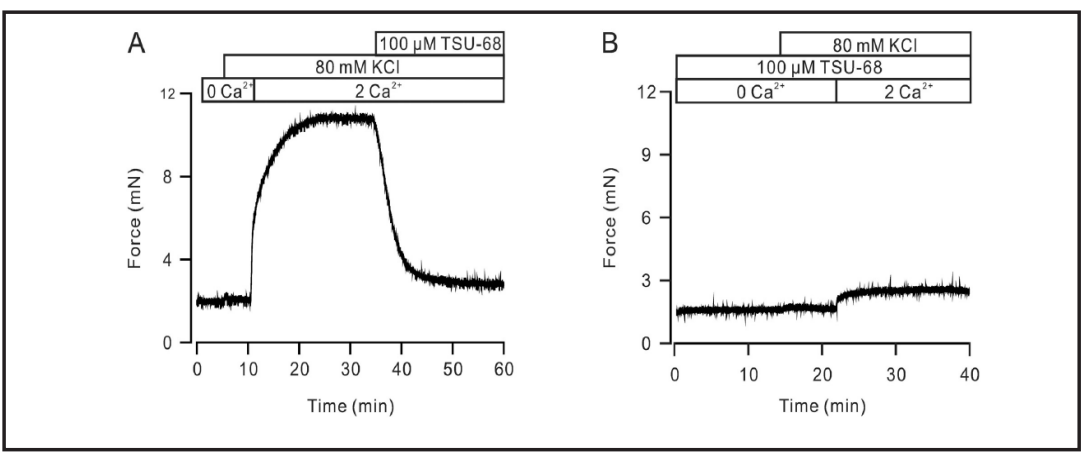
bited by TSU-68 ( $\mathrm{n}=6 / 6$ mice). (B) In the presence of $100 \mu \mathrm{M}$ TSU-68, a Ca ${ }^{2+}$ restoration-provoked contraction was not noted $(\mathrm{n}=6 / 6$ mice).

a tension measurement to calculate a proper effective concentration (EC) of $\mathrm{K}^{+}$was performed (for all online suppl. material, see www.karger.com/doi/10.1159/000475653, Fig. S1). High $\mathrm{K}^{+}$was shown to induce the gradual contraction of ASM in a dose-dependent manner (see supplementary material, Fig. S1A). According to the dose-contraction curve (see supplementary material, Fig. S1B) and the results of our previous studies [39, 44], the effective concentration $100 \%\left(\mathrm{EC}_{100}\right)$ was $80 \mathrm{mM}$, which could maximally activate $\mathrm{Ca}^{2+}$ permeable channels; thus, this concentration was applied. As shown in Fig. 1A, the precontraction induced by high $\mathrm{K}^{+}(80 \mathrm{mM})$ was reversed by TSU-68 in a dose-dependent manner. According to the dose-contraction curve shown in Fig. 1B, the maximal relaxation was calculated as $98.46 \pm 1.63 \%$. The half-maximal inhibition $\left(\mathrm{IC}_{50}\right)$ was $29.08 \pm 8.70 \mu \mathrm{M}(\mathrm{n}$ $=7 / 7$ mice). Fig. $1 \mathrm{C}$ shows that $10 \mu \mathrm{M}$ nifedipine, a selective blocker of VDCCs, completely reversed the high $\mathrm{K}^{+}$-induced contraction in ASM ( $\mathrm{n}=6 / 6$ mice), which confirmed that the contraction was induced via the opening of VDCCs. Fig. 1D shows that $100 \mu \mathrm{M}$ TSU-68 had no effect on resting mouse tracheas ( $\mathrm{n}=4 / 4$ mice). These results indicated that TSU-68 inhibited high $\mathrm{K}^{+}$-induced pre-contraction in a dose-dependent manner. Furthermore, the 
Fig. 3. TSU-68 blocked VDCC currents. (A) The VDCC currents of single mouse ASM cells were measured. (B) VDCC currents were recorded following depolarization and were blocked by TSU-68 or nifedipine. (C) The $I-V$ relationship was constructed based on the results of 6 experiments.

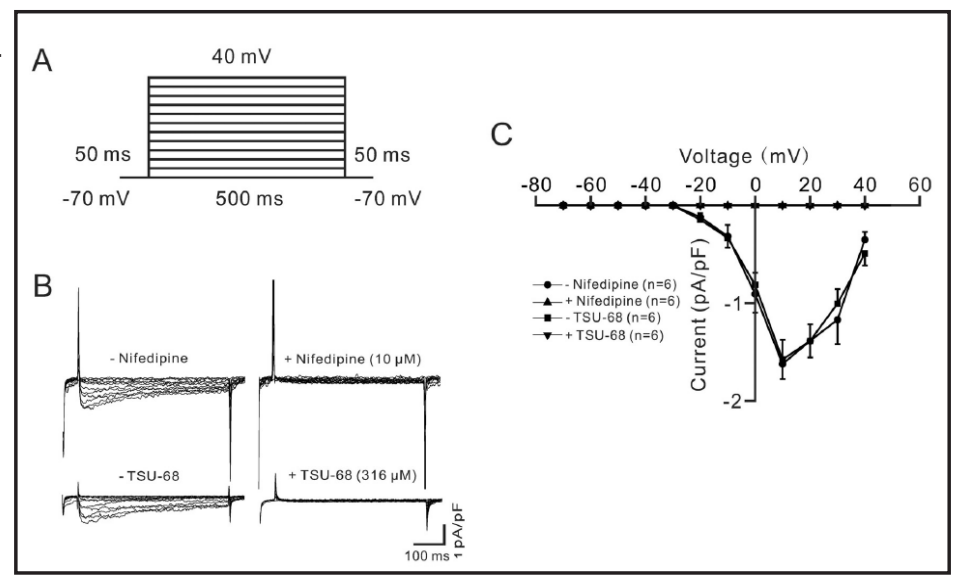

relaxant effect of nifedipine suggested that VDCC participated in high $\mathrm{K}^{+}$-induced contraction and also might be involved in TSU-68-induced relaxation.

\section{TSU-68 blocked high $\mathrm{K}^{+}$-evoked $\mathrm{Ca}^{2+}$ influx}

A previous study indicated that contracted ASM was relaxed by blocking VDCC via an intracellular $\mathrm{Ca}^{2+}$ decrease [45]. Meanwhile, a VEGF-evoked $\mathrm{Ca}^{2+}$ release was blocked by pre-treatment with TSU-68 [16]. To further characterize the relaxant mechanism of TSU68 shown in Fig. 1, the following experiments were designed to explore the role of calcium in TSU-68-induced relaxation. Under $\mathrm{Ca}^{2+}$-free conditions, high $\mathrm{K}^{+}$-induced contraction did not occur (Fig. 2A), indicating that calcium influx was necessary for VDCC opening-induced contraction. Following $\mathrm{Ca}^{2+}$ restoration, the contraction that immediately appeared was almost completely inhibited by $100 \mu \mathrm{M}$ TSU-68 (Fig. 2A) ( $\mathrm{n}=6 / 6$ mice). Meanwhile, high $\mathrm{K}^{+}$ failed to induce a pre-contraction under $\mathrm{Ca}^{2+}$-free conditions in the presence of $100 \mu \mathrm{M}$ TSU68 , and even after $\mathrm{Ca}^{2+}$ restoration, the ASM contraction was not obvious ( $p=0.54$ ) (Fig. 2B) $\left(\mathrm{n}=6 / 6\right.$ mice). These data suggested that blocking high $\mathrm{K}^{+}$-induced $\mathrm{Ca}^{2+}$ influx was involved in the relaxant effects of TSU-68.

\section{TSU-68 blocked VDCC currents}

To further confirm the involvement of VDCC in TSU-68-induced relaxation on ASM, particular VDCC currents were measured using the whole-cell patch-clamp technique. As shown in Fig. 3A, the currents were recorded with voltage steps from $-70 \mathrm{mV}$ to $+40 \mathrm{mV}$. As a positive control, the currents were blocked by the specific blocker nifedipine, which indicated that VDCC currents were recorded (Fig. 3B, top). The currents were then removed by $316 \mu \mathrm{M}$ TSU-68 (Fig. 3B, bottom), while $100 \mu \mathrm{M}$ TSU-68 partially blocked the currents (see supplementary material, Fig. S2). As a type of voltage-dependent channel, the voltagedependent property of VDCC was examined by calculating the current-voltage $(I-V)(\mathrm{n}=$ $6 / 6$ mice, Fig. 3C), and the results suggested that TSU-68 inhibited VDCC currents. Taken together, TSU- 68 was able to relax high $\mathrm{K}^{+}$-induced ASM contraction by blocking VDCC and then decreasing intracellular $\mathrm{Ca}^{2+}$.

\section{TSU-68 relaxed ACh-induced pre-contraction in a dose-dependent manner}

The regulation of calcium is a complicated process that involves a series of ion channels $[16,45]$. We sought to determine whether any other ion channels besides VDCCs might participate in TSU-68-induced relaxation. ACh, a known muscarinic receptor agonist, induced ASM contraction through both VDCCs and NSCCs $[46,47]$. In the following experiments, ACh was chosen to pre-contract ASM. The ACh concentration was determined by measuring the dose-dependent tension, as shown in Fig. S3 (see supplementary material). ACh could stimulate ASM contraction gradually and in a dose-dependent manner (see supplementary material, Fig. S3A). The generated dose-response curve (see supplementary material, Fig. 
A

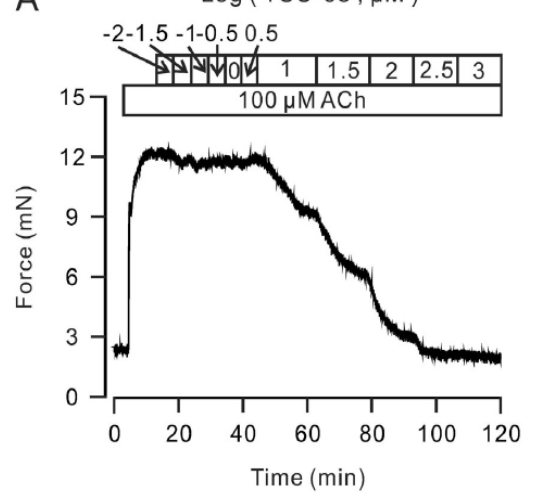

B

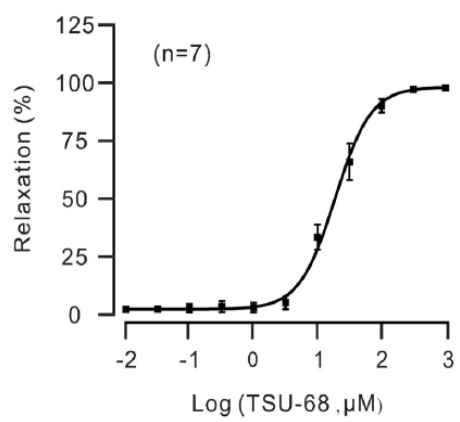

Fig. 4. TSU-68 inhibited ACh-induced pre-contraction in mouse tracheal rings. (A) ACh induced a steady-state contraction in a mouse tracheal ring, which was inhibited by TSU-68 in a concentration-dependent manner. (B) Dose-relaxation curve of TSU-68 based on the results of 7 different experiments (shown in A).

Fig. 5. TSU-68 inhibited ACh-induced contraction, which was isolated by nifedipine. (A) Nifedipine partly reduced the ACh-induced contraction. The resistant contraction was inhibited by TSU-68 ( $n=7 / 7$ mice). (B) In the presence of nifedipine, ACh induced a typical contraction, which was dose-dependently inhibited by TSU68. (C) The summary of results from 7 experiments.

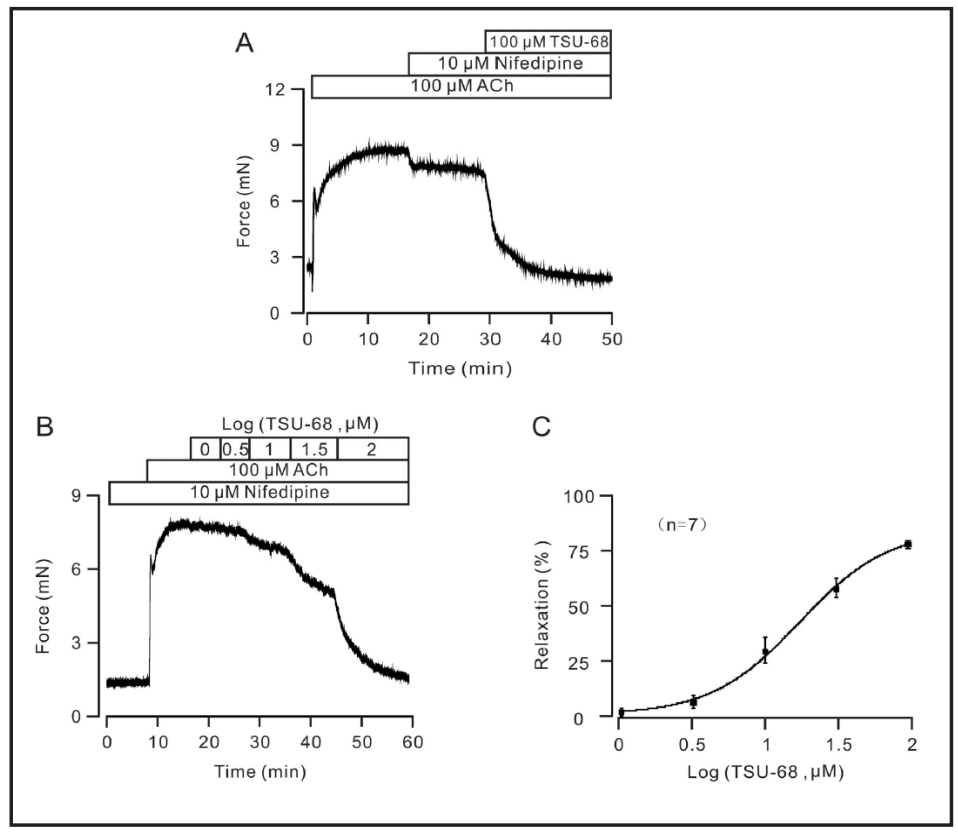

S3B) and the results of our previous study $[23,40]$ indicated that $100 \mu \mathrm{M} \mathrm{ACh}\left(\mathrm{EC}_{75}=\right.$ $97.93 \mu \mathrm{M}$ ) was sufficient for our subsequent experiments. As shown in Figure 4, TSU-68 was able to completely relax $100 \mu \mathrm{M}$ ACh-induced pre-contraction in a dose-dependent manner (Fig. 4A). The relaxation curve was then measured and was shown in Fig. 4B. The maximal relaxation was $97.86 \pm 1.86 \%$, and the $\mathrm{IC}_{50}$ was $20.62 \pm 5.91 \mu \mathrm{M}(\mathrm{n}=7 / 7$ mice). As shown in Fig. 5, to identify the role of NSCCs, VDCCs were excluded with the specific blocker nifedipine before or after ACh addition. In the presence of ACh, induced pre-contraction was partially reversed by $10 \mu \mathrm{M}$ nifedipine $(22 \% \pm 3.98 \%, p<0.001)$. Subsequently, $100 \mu \mathrm{M}$ TSU-68 was able to almost completely relax resistant tension $(96.82 \% \pm 4.85 \%)$ (Fig. 5A, $\mathrm{n}=7 / 7$ mice). In the presence of nifedipine, ACh-induced pre-contraction was also relaxed by TSU-68 in a dose-dependent manner (Fig. 5B). In Fig. 5C, the curve showed that in the presence of nifedipine, the maximal inhibition induced by $100 \mu \mathrm{M}$ TSU-68 was $78.05 \% \pm$ $1.5 \%$, with an $\mathrm{IC}_{50}$ of $17.68 \mu \mathrm{M}(\mathrm{n}=7 / 7$ mice). These experiments indicated that in addition to VDCCs, NSCCs or intracellular calcium release could also be evoked by ACh and thus might participate in TSU-68-induced relaxation. 
Fig. 6. TSU-68 blocked ACh-induced $\mathrm{Ca}^{2+}$ influx. (A) In the presence of ACh and under $\mathrm{Ca}^{2+}$-free conditions ( $0 \mathrm{mM} \mathrm{Ca}^{2+}+0.5 \mathrm{mM}$ EGTA), ACh induced a rapid, transient contraction. Following the addition of $2 \mathrm{mM} \mathrm{Ca}^{2+}$, a strong, sustained contraction occurred, which was fully relaxed by TSU-68. (B) In the presence of TSU-68, a $\mathrm{Ca}^{2+}$ restoration-induced contraction by $\mathrm{ACh}$ was not observed. (C) In the presence of nifedipine, TSU-68 relaxed the ACh-evoked contraction with 2 $\mathrm{mM} \mathrm{Ca}{ }^{2+}$ restoration.
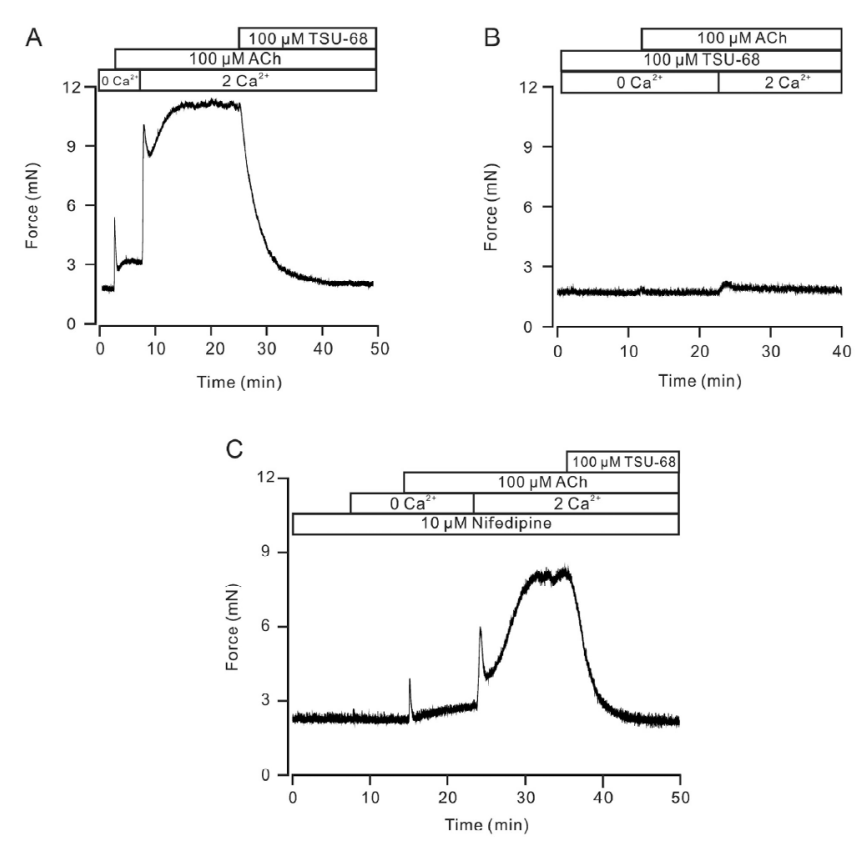

Fig. 7. TSU-68 blocked NSCC currents. (A) The ramp clamp protocol was used to measure NSCC currents in single ASM cells. (B) I-t relationships were plotted at $\mathrm{Vm}=$ $-70 \mathrm{mV}$. (C) The slope currents at times $a, b$, and $c$ in $B$.

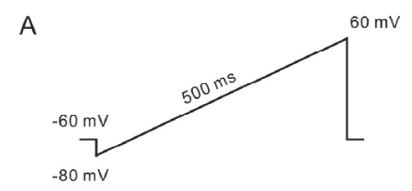

B

C

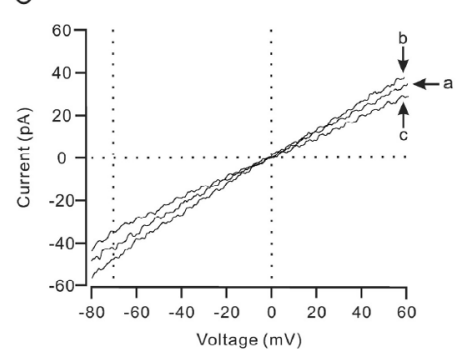

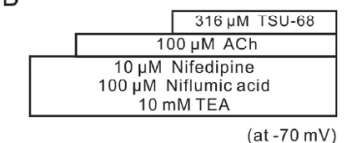

(at $-70 \mathrm{mV}$ )

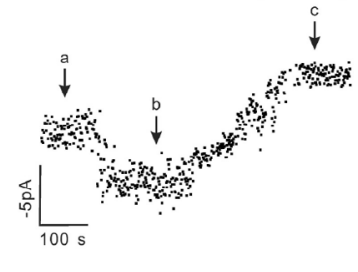

TSU-68 blocked ACh-evoked Ca ${ }^{2+}$ influx

In addition to NSCCs, calcium influx or intracellular calcium release could not be excluded from participating in TSU-68-induced relaxation. To further explore the role of calcium in TSU-68-evoked relaxation, $\mathrm{Ca}^{2+}$ influx was studied under ACh-induced pre-contraction. As shown in Fig. $6 \mathrm{~A}$, in the presence of nifedipine $(10 \mu \mathrm{M})$ under $\mathrm{Ca}^{2+}$-free conditions, ACh induced a sharp contraction, indicating that there was a transient release of intracellular calcium. Subsequently, the addition of $2 \mathrm{mM} \mathrm{Ca}^{2+}$ triggered a sustained contraction, which was completely reversed by $100 \mu \mathrm{M}$ TSU-68 ( $\mathrm{n}=6 / 6$ mice). In the presence of $100 \mu \mathrm{M}$ TSU68 , an ACh-induced transient release of intracellular calcium was not observed. With the restoration of $2 \mathrm{mM} \mathrm{Ca}^{2+}$, sustained contraction also did not occur (Fig. 6B). In presence of nifedipine, VDCCs were blocked and NSCCs were isolated, as shown in Fig. 6C. Under $\mathrm{Ca}^{2+}-$ free conditions, intracellular $\mathrm{Ca}^{2+}$ transiently released after the addition of $100 \mu \mathrm{M} \mathrm{ACh}$. With the restoration of $2 \mathrm{mM} \mathrm{Ca}^{2+}$, a sustained contraction was induced that was subsequently reversed by $100 \mu \mathrm{M}$ TSU-68. These results indicated that $\mathrm{Ca}^{2+}$ influx played an important role 

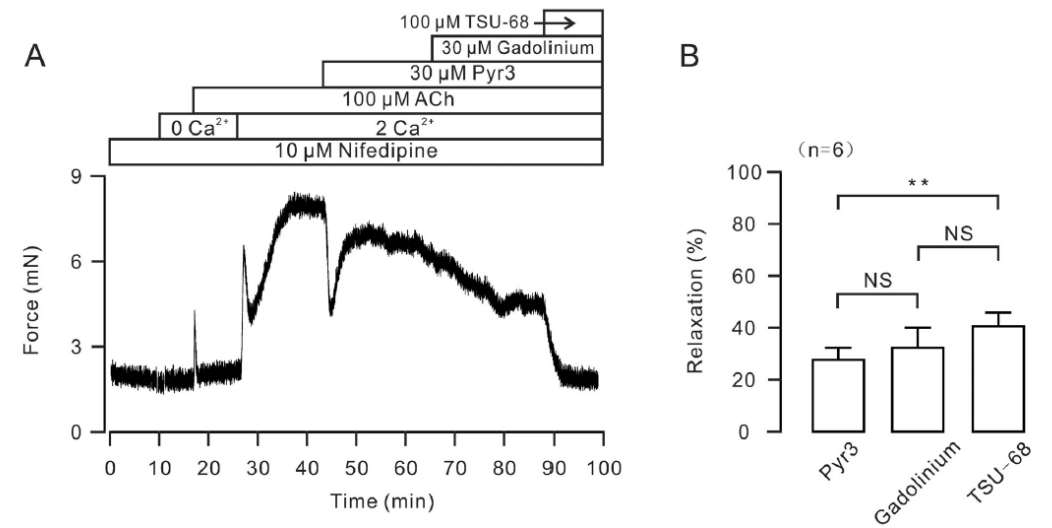

Fig. 8. ACh-induced contraction was inhibited by Pyr3, gadolinium, and TSU-68. (A) In the presence of nifedipine and $2 \mathrm{mM} \mathrm{Ca}^{2+}$, Pyr3, gadolinium, and TSU-68 relaxed the ACh-induced contraction, sequentially. (B) The bar graph showed the average reduction of Pyr3, gadolinium, and TSU-68, respectively, from 6 experiments. NS, not significant; ${ }^{* *}, p<0.01$.

in ACh-induced contraction. Specifically, TSU-68 could inhibit ACh-induced intracellular $\mathrm{Ca}^{2+}$ release and extracellular $\mathrm{Ca}^{2+}$ influx.

\section{TSU-68 blocked NSCC currents}

To further confirm the role of NSCCs in TSU-68-induced relaxation, whole-cell patchclamp was used to measure ACh-induced NSCC currents in the absence or presence of TSU68 (Fig. 7). As shown in Fig. 7A, the NSCC current showed a ramp from $-80 \mathrm{mV}$ to $+60 \mathrm{mV}$. Nifedipine, NA and TEA were applied to block currents from VDCCs, $\mathrm{Cl}^{-}$channels and $\mathrm{K}^{+}$ channels, respectively. Thus, the residual current was the ACh-induced NSCC current. Then, the currents at $-70 \mathrm{mV}$ were measured and a current-time trace was plotted (Fig. 7B). The results showed that NSCC currents could be completely blocked by $316 \mu$ M TSU-68 (n = $6 / 6$ mice). Three representative ramp current traces at time points $a, b$, and $c$ are shown in Fig. 6C. Taken together, these results indicate that TSU-68 can inhibit ACh-induced NSCC currents.

TRPCs were involved in ACh-induced contraction

TRPC channels, which are important components of NSCC, played critical roles in mediating extracellular $\mathrm{Ca}^{2+}$ influx [48-52]. To further identify the NSCCs involved in TSU-68blocked $\mathrm{Ca}^{2+}$ influx at the molecular level, the TRPC3 inhibitor Pyr3 $[44,53]$ and gadolinium, which is a blocker of TRPC1, 3, 5, 6, and 7 [54], were applied sequentially. As shown in Fig. $8 \mathrm{~A}$ and $\mathrm{B}$, in the presence of nifedipine, $\mathrm{ACh}$ induced a transient contraction under $\mathrm{Ca}^{2+}$-free conditions, which indicated that intracellular $\mathrm{Ca}^{2+}$ was transiently released after the addition of ACh. With the restoration of $2 \mathrm{mM} \mathrm{Ca}^{2+}$, a sustained contraction was induced by ACh and was partially reduced by $30 \mu \mathrm{M}$ Pyr3 (the average relaxation percentage was $27.41 \pm 5.02 \%$, 6/6), $30 \mu \mathrm{M}$ gadolinium (the average relaxation percentage was $32.02 \pm 7.97 \%, 6 / 6$ ), and finally almost completely eliminated by $100 \mu \mathrm{M}$ TSU-68 (the average relaxation percentage was $40.45 \pm 5.38 \%, 6 / 6$ ). These results suggested that TRPC channels contributed to AChinduced contraction. Combined with the result shown in Fig. 6C, TRPC channels might be identified as important components in the process of TSU-68-blocked $\mathrm{Ca}^{2+}$ influx via NSCC.

\section{Discussion}

Angiogenesis is a complex process that is critical for tumor growth, invasion, and metastasis [55]. Currently, several small-molecule chemical compounds have been designed 


\section{Cellular Physiology Cell Physiol Biochem 2017;41:2350-2362

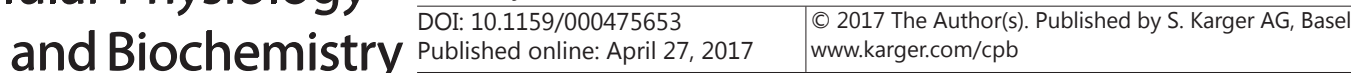 \\ Tan et al.: TSU-68 Relaxes Smooth Muscle in the Mouse Airway}

for oncology therapeutics according to their antiangiogenic characteristics [33]. Due to similar pathophysiological processes (inflammation, extracellular matrix proliferation, and angiogenesis) involved in both cancer and chronic disease, an increasing number of anticancer agents are being tested for treating chronic respiratory disease and particularly pulmonary disease [25]. For example, the antitumor drugs BIBF1120, SCH-527123, and gefinitib play new roles in the clinical treatment of chronic respiratory disease $[27,31,56]$.

The tyrosine kinase inhibitor TSU-68 is now known as an antiangiogenic small-molecule compound and has been widely used in antitumor therapy [36, 37]. For decades, it has been known that tyrosine kinases induce muscle contraction, which indicated that tyrosine kinase inhibitors may play an important role in muscle relaxation [57-62]. In the current study, we investigated the relaxant effects of TSU-68 in agonist-induced ASM contraction and the underlying mechanisms. We first examined whether TSU-68 could relax pre-contracted ASM. A high concentration of $\mathrm{K}^{+}$and ACh were employed to evoke muscle contraction, and we found that TSU-68 relaxed high $\mathrm{K}^{+}$- or ACh-pre-contracted mouse ASM in a dose-dependent manner (Figs. 1, 4 and 5). A recent study demonstrated that TSU-68 inhibited $\mathrm{Ca}^{2+}$ release [16]. Meanwhile, NSCCs and VDCCs are two types of ion channels that are critical for $\mathrm{Ca}^{2+}$ signaling and were shown to be involved in ASM contraction [46, 47, 63, 64]. The relaxant mechanisms of TSU-68, VDCCs, NSCCs, and $\mathrm{Ca}^{2+}$ influx were further examined. The results indicated that calcium influx might participate in TSU-68-induced relaxation by blocking VDCCs and NSCCs (Figs. 2 and 6). Specially, TRPC channels, as an important component of NSCC, were likely to be involved in this process (Figs. 6C and 8). It should be noted that except for VDCC and NSCC, $\mathrm{Na}^{+} / \mathrm{Ca}^{2+}$ exchangers (NCX) also play a critical role in mediating intracellular $\mathrm{Ca}^{2+}$ oscillation [65]. Whether NCX was involved in the blockage of $\mathrm{Ca}^{2+}$ influx by TSU-68 must be explored in additional research studies.

To further demonstrate the roles of VDCCs and NSCCs in TSU-68-induced relaxation, VDCC or NSCC currents were measured. We found that TSU-68 was able to completely inhibit both VDCC and NSCC currents (Figs. 3 and 7). Tyrosine kinase-induced smooth muscle contraction is a complicated process that involves plasma membrane depolarization [61] and the phosphorylation of a series of ACh-related receptors [66, 67]. In our study, TSU68 , as a tyrosine kinase inhibitor, may have indirectly polarized the plasma membrane to block VDCCs or may have directly dephosphorylated the ACh-related protein kinase K (PKC) pathway to block NSCCs. Both processes decrease calcium influx, thereby inducing muscle relaxation.

Overall, the tyrosine kinase inhibitor TSU-68 showed relaxant effects on pre-contracted ASM. These findings indicated that TSU-68 may be a potential treatment for abnormal airway contractions. However, the current conclusion was obtained based on data from in vitro mouse experiments. To definitively describe the effects of TSU-68 in clinical applications, further investigation is necessary. In future studies, additional experiments, including tissue toxicity detection, nasal inhalation in a pulmonary disease model, and others, will be needed. In the future, the drug should also be applied to human tracheas in the clinic.

\section{Conclusion}

In summary, our research indicated that TSU-68 can relax pre-contracted mouse ASM by inhibiting calcium influx through blocking VDCCs and NSCCs. Our research suggests a new role for TSU-68 in treating abnormally contracted ASM that should be further explored.

\section{Abbreviations}

ACh (acetylcholine chloride); ASM (airway smooth muscle); COPD (chronic obstructive pulmonary disease); CXCR (CXC chemokine receptors); EC (effective concentration); FGF (fibroblast growth factor); FGFR (fibroblast growth factor receptor); $\mathrm{IC}_{50}$ (half-maximal 


\section{Cellular Physiology Cell Physiol Biochem 2017;41:2350-2362

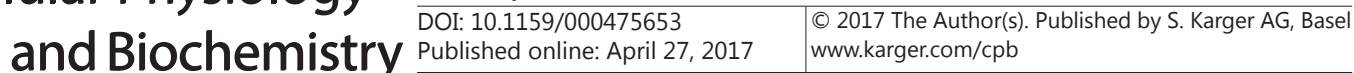 \\ Tan et al.: TSU-68 Relaxes Smooth Muscle in the Mouse Airway}

inhibition); IPF (idiopathic pulmonary fibrosis); NA (niflumic acid); NSCCs (non-selective cation channels); NSCLC (non-small cell lung cancer); PDGF (platelet-derived growth factor); PDGFR (platelet-derived growth factor receptor); PKC (protein kinase C); Pyr3 (pyrazole 3); SPF (specific pathogen-free); TEA (tetraethylammonium chloride); TRP (transient receptor potential); TRPC (transient receptor potential canonical); VDCCs (voltage-dependent $\mathrm{Ca}^{2+}$ channels); VEGF (vascular endothelial growth factor); VEGFR (vascular endothelial growth factor receptor).

\section{Acknowledgments}

This project was supported by a grant from the Fund for Distinguished Young Scholars of Hubei Province to Jinhua Shen (Grant No. 2012FFA028), the Sub-Project of the National Science and Technology Support Plan (2012BAI39B01), and grants from the National Natural Science Foundation of China (Grant Nos. 81170227 and 31101047) to Jinhua Shen and to Lu Xue. This project was also supported by funds granted to Qing-Hua Liu (CZW15025 and CZW15012) and the Fundamental Research Funds for the Central Universities, SouthCentral University for Nationalities (CZY17008).

\section{Disclosure Statement}

All authors report they have no conflicts of interest pertaining to this study.

\section{References}

1 Vestbo J, Hurd SS, Agusti AG, Jones PW, Vogelmeier C, Anzueto A, Barnes PJ, Fabbri LM, Martinez FJ, Nishimura M, Stockley RA, Sin DD, Rodriguez-Roisin R: Global strategy for the diagnosis, management, and prevention of chronic obstructive pulmonary disease: GOLD executive summary. Am J Respir Crit Care Med 2013;187:347-365.

2 Patel JG, Nagar SP, Dalal AA: Indirect costs in chronic obstructive pulmonary disease: a review of the economic burden on employers and individuals in the United States. Int J Chron Obstruct Pulmon Dis 2014;9:289-300.

3 Moorman JE, Akinbami LJ, Bailey CM, Zahran HS, King ME, Johnson CA, Liu X: National surveillance of asthma: United States, 2001-2010. Vital Health Stat 3 2012;1-58.

-4 Akinbami LJ, Moorman JE, Bailey C, Zahran HS, King M, Johnson CA, Liu X: Trends in asthma prevalence, health care use, and mortality in the United States, 2001-2010. NCHS Data Brief 2012;1-8.

-5 Angelis N, Porpodis K, Zarogoulidis P, Spyratos D, Kioumis I, Papaiwannou A, Pitsiou G, Tsakiridis K, Mpakas A, Arikas S, Tsiouda T, Katsikogiannis N, Kougioumtzi I, Machairiotis N, Argyriou M, Kessisis G, Zarogoulidis K: Airway inflammation in chronic obstructive pulmonary disease. J Thorac Dis 2014;6 Suppl 1:S167-172.

-6 Wiegman CH, Michaeloudes C, Haji G, Narang P, Clarke CJ, Russell KE, Bao W, Pavlidis S, Barnes PJ, Kanerva J, Bittner A, Rao N, Murphy MP, Kirkham PA, Chung KF, Adcock IM: Oxidative stress-induced mitochondrial dysfunction drives inflammation and airway smooth muscle remodeling in patients with chronic obstructive pulmonary disease. J Allergy Clin Immunol 2015;136:769-780.

7 Barnes PJ: Cellular and molecular mechanisms of chronic obstructive pulmonary disease. Clin Chest Med 2014;35:71-86.

8 Hofheinz RD, Ronellenfitsch U, Kubicka S, Falcone A, Burkholder I, Hacker UT: Treatment with Antiangiogenic Drugs in Multiple Lines in Patients with Metastatic Colorectal Cancer: Meta-Analysis of Randomized Trials. Gastroenterol Res Pract 2016;2016:9189483.

-9 Ferrara N: Vascular endothelial growth factor as a target for anticancer therapy. Oncologist 2004;9 Suppl 1:2-10. 


\section{Cellular Physiology Cell Physiol Biochem 2017;41:2350-2362

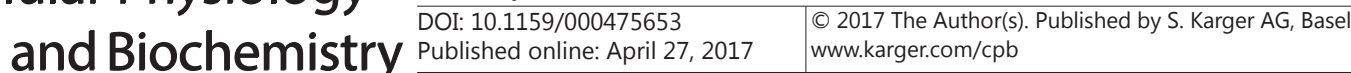

10 Hicklin DJ, Ellis LM: Role of the vascular endothelial growth factor pathway in tumor growth and angiogenesis. J Clin Oncol 2005;23:1011-1027.

11 Ferrara N, Gerber HP, LeCouter J: The biology of VEGF and its receptors. Nat Med 2003;9:669-676.

12 Kerbel RS: Tumor angiogenesis. N Engl J Med 2008;358:2039-2049.

13 Antonioli L, Blandizzi C, Pacher P, Hasko G: Immunity, inflammation and cancer: a leading role for adenosine. Nat Rev Cancer 2013;13:842-857.

-14 Kohn EC, Alessandro R, Spoonster J, Wersto RP, Liotta LA: Angiogenesis: role of calcium-mediated signal transduction. Proc Natl Acad Sci U S A 1995;92:1307-1311.

15 Whitfield JF: Calcium signals and cancer. Crit Rev Oncog 1992;3:55-90.

-16 Favia A, Desideri M, Gambara G, D'Alessio A, Ruas M, Esposito B, Del Bufalo D, Parrington J, Ziparo E, Palombi F, Galione A, Filippini A: VEGF-induced neoangiogenesis is mediated by NAADP and two-pore channel-2-dependent Ca2+ signaling. Proc Natl Acad Sci U S A 2014;111:E4706-4715.

17 Monteith GR, Davis FM, Roberts-Thomson SJ: Calcium channels and pumps in cancer: changes and consequences. J Biol Chem 2012;287:31666-31673.

18 Kranenburg AR, Willems-Widyastuti A, Mooi WJ, Saxena PR, Sterk PJ, de Boer WI, Sharma HS: Chronic obstructive pulmonary disease is associated with enhanced bronchial expression of FGF-1, FGF-2, and FGFR-1. J Pathol 2005;206:28-38.

19 Whitsett JA, Wert SE, Weaver TE: Diseases of pulmonary surfactant homeostasis. Annu Rev Pathol 2015;10:371-393.

20 Wollin L, Maillet I, Quesniaux V, Holweg A, Ryffel B: Antifibrotic and anti-inflammatory activity of the tyrosine kinase inhibitor nintedanib in experimental models of lung fibrosis. J Pharmacol Exp Ther 2014;349:209-220.

-21 Papp A, Bene Z, Gaspar I, Nagy B, Jr., Kadar L, Marialigeti T, Banfi A, Baktai G, Balla G, Nagy B: Decreased VEGF Level Is Associated with Elevated Ferritin Concentration in Bronchoalveolar Lavage Fluid of Children with Interstitial Lung Diseases. Respiration 2015;90:443-450.

-22 Dupin I, Allard B, Ozier A, Maurat E, Ousova O, Delbrel E, Trian T, Bui HN, Dromer C, Guisset O, Blanchard E, Hilbert G, Vargas F, Thumerel M, Marthan R, Girodet PO, Berger P: Blood fibrocytes are recruited during acute exacerbations of chronic obstructive pulmonary disease through a CXCR4-dependent pathway. J Allergy Clin Immunol 2016;137:1036-1042 e1031-1037.

23 Wei MY, Xue L, Tan L, Sai WB, Liu XC, Jiang QJ, Shen J, Peng YB, Zhao P, Yu MF, Chen W, Ma LQ Zhai K, Zou C, Guo D, Qin G, Zheng YM, Wang YX, Ji G, Liu QH: Involvement of large-conductance Ca2+-activated K+ channels in chloroquine-induced force alterations in pre-contracted airway smooth muscle. PLoS One 2015;10:e0121566.

24 Sathish V, Freeman MR, Long E, Thompson MA, Pabelick CM, Prakash YS: Cigarette Smoke and Estrogen Signaling in Human Airway Smooth Muscle. Cell Physiol Biochem 2015;36:1101-1115.

-25 Fujita Y, Abe R, Shimizu H: Clinical approaches toward tumor angiogenesis: past, present and future. Curr Pharm Des 2008;14:3820-3834.

-26 Hilberg F, Roth GJ, Krssak M, Kautschitsch S, Sommergruber W, Tontsch-Grunt U, Garin-Chesa P, Bader G, Zoephel A, Quant J, Heckel A, Rettig WJ: BIBF 1120: triple angiokinase inhibitor with sustained receptor blockade and good antitumor efficacy. Cancer Res 2008;68:4774-4782.

-27 Roth GJ, Binder R, Colbatzky F, Dallinger C, Schlenker-Herceg R, Hilberg F, Wollin SL, Kaiser R: Nintedanib: from discovery to the clinic. J Med Chem 2015;58:1053-1063.

-28 Richeldi L, Costabel U, Selman M, Kim DS, Hansell DM, Nicholson AG, Brown KK, Flaherty KR, Noble PW, Raghu G, Brun M, Gupta A, Juhel N, Kluglich M, du Bois RM: Efficacy of a tyrosine kinase inhibitor in idiopathic pulmonary fibrosis. N Engl J Med 2011;365:1079-1087.

29 Richeldi L, du Bois RM, Raghu G, Azuma A, Brown KK, Costabel U, Cottin V, Flaherty KR, Hansell DM, Inoue Y, Kim DS, Kolb M, Nicholson AG, Noble PW, Selman M, Taniguchi H, Brun M, Le Maulf F, Girard M, Stowasser S, Schlenker-Herceg R, Disse B, Collard HR: Efficacy and safety of nintedanib in idiopathic pulmonary fibrosis. N Engl J Med 2014;370:2071-2082.

-30 Antoniu SA: Nintedanib (BIBF 1120) for IPF: a tomorrow therapy? Multidiscip Respir Med 2012;7:41.

-31 Song L, Tang H, Liu D, Song J, Wu Y, Qu S, Li Y: The Chronic and Short-Term Effects of Gefinitib on Airway Remodeling and Inflammation in a Mouse Model of Asthma. Cell Physiol Biochem 2016;38:194-206. 


\section{Cellular Physiology Cell Physiol Biochem 2017;41:2350-2362 and Biochemistry Published onine: April27, $2017 \quad \begin{aligned} & \text { DOI: 10.1159/000475653 } 2017 \text { The Author(s). Published by S. Karger AG, Basel } \\ & \text { www.karger.com/cpb }\end{aligned}$}

Tan et al.: TSU-68 Relaxes Smooth Muscle in the Mouse Airway

-32 Nair P, Gaga M, Zervas E, Alagha K, Hargreave FE, O'Byrne PM, Stryszak P, Gann L, Sadeh J, Chanez P: Safety and efficacy of a CXCR2 antagonist in patients with severe asthma and sputum neutrophils: a randomized, placebo-controlled clinical trial. Clin Exp Allergy 2012;42:1097-1103.

-33 Teicher BA: Antiangiogenic agents and targets: A perspective. Biochem Pharmacol 2011;81:6-12.

-34 Donnelly LE, Barnes PJ: Chemokine receptor CXCR2 antagonism to prevent airways inflammation. Drugs Future 2011;36:465.

-35 Li W, Yan S, Zhao J, Ding X, Zhang S, Wang D, Liu L, Peng W, Li H, Wang D, Liu Z, Li Y: Metoprolol Inhibits Cardiac Apoptosis and Fibrosis in a Canine Model of Chronic Obstructive Sleep Apnea. Cell Physiol Biochem 2015;36:1131-1141.

-36 Kanai F, Yoshida H, Tateishi R, Sato S, Kawabe T, Obi S, Kondo Y, Taniguchi M, Tagawa K, Ikeda M, Morizane C, Okusaka T, Arioka H, Shiina S, Omata M: A phase I/II trial of the oral antiangiogenic agent TSU-68 in patients with advanced hepatocellular carcinoma. Cancer Chemother Pharmacol 2011;67:315-324.

37 Toi M, Saeki T, Iwata H, Inoue K, Tokuda Y, Sato Y, Ito Y, Aogi K, Takatsuka Y, Arioka H: A multicenter phase II study of TSU-68, an oral multiple tyrosine kinase inhibitor, in combination with docetaxel in metastatic breast cancer patients with anthracycline resistance. Breast Cancer 2014;21:20-27.

- 38 Okamoto I, Yoshioka H, Takeda K, Satouchi M, Yamamoto N, Seto T, Kasahara K, Miyazaki M, Kitamura R, Ohyama A, Hokoda N, Nakayama H, Yoshihara E, Nakagawa K: Phase I clinical study of the angiogenesis inhibitor TSU-68 combined with carboplatin and paclitaxel in chemotherapy-naive patients with advanced non-small cell lung cancer. J Thorac Oncol 2012;7:427-433.

-39 Tan L, Chen W, Wei MY, Shen J, Yu MF, Yang G, Guo D, Qin G, Ji G, Liu QH: Relaxant action of plumula nelumbinis extract on mouse airway smooth muscle. Evid Based Complement Alternat Med 2015;2015:523640.

-40 Zhang T, Luo XJ, Sai WB, Yu MF, Li WE, Ma YF, Chen W, Zhai K, Qin G, Guo D, Zheng YM, Wang YX, Shen JH, Ji G, Liu QH: Non-selective cation channels mediate chloroquine-induced relaxation in precontracted mouse airway smooth muscle. PLoS One 2014;9:e101578.

41 Liu QH, Zheng YM, Korde AS, Yadav VR, Rathore R, Wess J, Wang YX: Membrane depolarization causes a direct activation of G protein-coupled receptors leading to local Ca2+ release in smooth muscle. Proc Natl Acad Sci U S A 2009;106:11418-11423.

42 Karaki H, Ozaki H, Hori M, Mitsui-Saito M, Amano K, Harada K, Miyamoto S, Nakazawa H, Won KJ, Sato K: Calcium movements, distribution, and functions in smooth muscle. Pharmacol Rev 1997;49:157-230.

43 Karaki H, Urakawa N, Kutsky P: Potassium-induced contraction in smooth muscle. Nihon Heikatsukin Gakkai Zasshi 1984;20:427-444.

44 Jiang QJ, Chen W, Dan H, Tan L, Zhu H, Yang G, Shen J, Peng YB, Zhao P, Xue L, Yu MF, Ma L, Si XT, Wang Z, Dai J, Qin G, Zou C, Liu QH: Cortex phellodendri Extract Relaxes Airway Smooth Muscle. Evid Based Complement Alternat Med 2016;2016:8703239.

45 Coelho RR, Souza EP, Soares PM, Meireles AV, Santos GC, Scarparo HC, Assreuy AM, Criddle DN: Effects of chloride channel blockers on hypotonicity-induced contractions of the rat trachea. Br J Pharmacol 2004;141:367-373.

-46 Fleischmann BK, Wang YX, Kotlikoff MI: Muscarinic activation and calcium permeation of nonselective cation currents in airway myocytes. Am J Physiol 1997;272:C341-349.

-47 Wang YX, Fleischmann BK, Kotlikoff MI: M2 receptor activation of nonselective cation channels in smooth muscle cells: calcium and Gi/G(o) requirements. Am J Physiol 1997;273:C500-508.

48 Ong HL, de Souza LB, Ambudkar IS: Role of TRPC Channels in Store-Operated Calcium Entry. Adv Exp Med Biol 2016;898:87-109.

49 Ong HL, de Souza LB, Cheng KT, Ambudkar IS: Physiological functions and regulation of TRPC channels. Handb Exp Pharmacol 2014;223:1005-1034.

-50 Cheng KT, Ong HL, Liu X, Ambudkar IS: Contribution and regulation of TRPC channels in store-operated Ca2+ entry. Curr Top Membr 2013;71:149-179.

51 Montell C, Birnbaumer L, Flockerzi V: The TRP channels, a remarkably functional family. Cell 2002;108:595-598.

-52 Billington CK, Hall IP, Nelson CP: Mechanisms Underlying Ca2+ Store Refilling in Airway Smooth Muscle; in Wang Y-X (ed): Calcium Signaling In Airway Smooth Muscle Cells. Switzerland, Springer International Publishing, 2014, pp. 177-193. 


\section{Cellular Physiology Cell Physiol Biochem 2017;41:2350-2362 \begin{tabular}{l|l} 
DOI: 10.1159/000475653 & $\begin{array}{l}\text { O 2017 The Author(s). Published by S. Karger AG, Basel } \\
\text { www.karger.com/cpb }\end{array}$ \\
\hline
\end{tabular}

53 Rogerio AP, Carlo T, Ambrosio SR: Bioactive Natural Molecules and Traditional Herbal Medicine in the Treatment of Airways Diseases. Evid Based Complement Alternat Med 2016;2016:9872302.

54 Xiao J-H, Wang Y-X, Zheng Y-M: Transient Receptor Potential and Orai Channels in Airway Smooth Muscle Cells; in Wang Y-X (ed): Calcium Signaling In Airway Smooth Muscle Cells. Switzerland, Springer International Publishing, 2014, pp. 35-48.

55 Nishida N, Yano H, Nishida T, Kamura T, Kojiro M: Angiogenesis in cancer. Vasc Health Risk Manag 2006;2:213-219.

-56 Dwyer MP, Yu Y, Chao J, Aki C, Chao J, Biju P, Girijavallabhan V, Rindgen D, Bond R, Mayer-Ezel R, Jakway J, Hipkin RW, Fossetta J, Gonsiorek W, Bian H, Fan X, Terminelli C, Fine J, Lundell D, Merritt JR, Rokosz LL, Kaiser B, Li G, Wang W, Stauffer T, Ozgur L, Baldwin J, Taveras AG: Discovery of 2-hydroxy-N,N-dimethyl-3\{2-[[(R)-1-(5- methylfuran-2-yl)propyl]amino]-3,4-dioxocyclobut-1-enylamino\}benzamide (SCH 527123): a potent, orally bioavailable CXCR2/CXCR1 receptor antagonist. J Med Chem 2006;49:7603-7606.

57 Di Salvo J, Steusloff A, Semenchuk L, Satoh S, Kolquist K, Pfitzer G: Tyrosine kinase inhibitors suppress agonist-induced contraction in smooth muscle. Biochem Biophys Res Commun 1993;190:968-974.

58 Janssen LJ, Lu-Chao H, Netherton S: Excitation-contraction coupling in pulmonary vascular smooth muscle involves tyrosine kinase and Rho kinase. Am J Physiol Lung Cell Mol Physiol 2001;280:L666-674.

59 Hollenberg MD: Tyrosine kinase pathways and the regulation of smooth muscle contractility. Trends Pharmacol Sci 1994;15:108-114.

60 Mills RD, Mita M, Nakagawa J, Shoji M, Sutherland C, Walsh MP: A role for the tyrosine kinase Pyk2 in depolarization-induced contraction of vascular smooth muscle. J Biol Chem 2015;290:8677-8692.

61 Mills RD, Mita M, Walsh MP: A role for the Ca(2+)-dependent tyrosine kinase Pyk2 in tonic depolarizationinduced vascular smooth muscle contraction. J Muscle Res Cell Motil 2015;36:479-489.

62 Mita M, Tanaka H, Yanagihara H, Nakagawa J, Hishinuma S, Sutherland C, Walsh MP, Shoji M: Membrane depolarization-induced RhoA/Rho-associated kinase activation and sustained contraction of rat caudal arterial smooth muscle involves genistein-sensitive tyrosine phosphorylation. J Smooth Muscle Res 2013;49:26-45.

63 Gilani AH, Khan AU, Jabeen Q, Subhan F, Ghafar R: Antispasmodic and blood pressure lowering effects of Valeriana wallichii are mediated through K+ channel activation. J Ethnopharmacol 2005;100:347-352.

-64 Soder RP, Petkov GV: Large conductance Ca2+ -activated K+ channel activation with NS1619 decreases myogenic and neurogenic contractions of rat detrusor smooth muscle. Eur J Pharmacol 2011;670:252-259.

65 Khananshvili D: Sodium-calcium exchangers (NCX): molecular hallmarks underlying the tissue-specific and systemic functions. Pflugers Arch 2014;466:43-60.

66 Inoue R, Waniishi Y, Yamada K, Ito Y: A possible role of tyrosine kinases in the regulation of muscarinic receptor-activated cation channels in guinea pig ileum. Biochem Biophys Res Commun 1994;203:13921397.

67 Wang T, Cleary RA, Wang R, Tang DD: Glia maturation factor-gamma phosphorylation at Tyr-104 regulates actin dynamics and contraction in human airway smooth muscle. Am J Respir Cell Mol Biol 2014;51:652659. 